\title{
Stimulation of p-Aminohippurate Extraction in the Maturing Rabbit Kidney
}

\author{
MATTHEW R. KAPLAN AND JOHN E. LEWY ${ }^{(32)}$ \\ Division of Pediatric Nephrology, Cornell University Medical College, New York, New York, USA
}

\begin{abstract}
Summary
In vivo studies were performed to evaluate maturational changes in $\mathrm{PAH}$ extraction ( $\left.\mathrm{E}_{\mathrm{PAH}}\right)$ in the rabbit and to determine whether accelerated maturation of this process could be achieved. Fiftyfour animals were injected with penicillin before study at 10, 14, $\mathbf{2 1}$, or $\mathbf{2 8}$ days of life. Forty-eight rabbits served as saline-injected controls. PAH extraction in controls increased from $29.3 \pm 2.4 \%$ at 10 days of age to $35.9 \pm 3.3 \%$ at 14 days, $59.7 \pm 3.5 \%$ at 21 days, $71.6 \pm 1.9 \%$ at 28 days, and $72.7 \pm 2.3 \%$ at 35 days of life. Penicillin injection on the 3 days before study resulted in enhancement of $E_{\mathrm{PAH}}$ on days 10 and 14 to $42.7 \pm 2.4 \%$ and $65.0 \pm 3.2 \%$ $(P<0.005)$. On days 21 and 28 less stimulation was noted $(68.7$ $\pm 2.3 \% ; 76.0 \pm 4.1 \%)$. Preinjection on days $6-9$ with study delayed to day 14 also led to augmentation $(46.7 \pm 3.7 \% P<0.05)$ but less than that achieved after injection on days 10-13. These data suggest that $E_{P A H}$ stimulation may be transient, descreases as maturation is approached and is likely related to substrate availability.
\end{abstract}

\section{Speculation}

The mechanism(s) responsible for the transport of organic anions in young rabbits responds to factors related to subtrate availability by increasing the rate of transfer of these substances. Enzyme systems, tubular mass, transport proteins, and blood flow distribution may be involved; singly, or in combination.

The extraction of organic anions is an example of a process which is not fully operational at birth or in the neonatal period $(12,21,28)$. PAH, an organic anion, is concentrated and secreted by the cells of the proximal tubule (25). The rate of secretion is higher in the straight than the convoluted portion (23). Transfer of PAH from peritubular capillary to lumen appears to occur in two steps. First, concentration of the anion within the tubular cell, then secretion into the lumen down a concentration gradient. The active, concentrating step is thought to involve both an energydependent and an enzyme-dependent process $(6,7,11)$. The extraction of $p$-aminohippurate $\left(\mathrm{E}_{\mathrm{PAH}}\right)$ has been noted to be low in newborn rats (12), in human infants (2), and in puppies (15). Hirsch and Hook $(8-10,13)$, utilizing the in vitro renal cortical slice technique of Cross and Taggart (3), studied the ability of slices of the kidney from newborn rabbits to accumulate PAH from a bathing medium. They found a gradual increase in the slice to medium ratio of PAH from 1 day to 2 weeks of age, and a more rapid increase from 2 weeks to a peak at 4 weeks of age. After 4 weeks, a decline of $S / M$ ratio to adult values was noted. A similar pattern has been observed in puppies (21). Hirsch and Hook also demonstrated an increment in the uptake of PAH by kidney slices from immature rabbits following stimulation with an organic anion, penicillin. However, the increase in PAH transport was noted only up to 2 weeks of age. Animals pretreated with penicillin had increased kidney weight to body weight ratios compared to controls at 2 weeks, but not at 4 weeks of age $(8,9)$.
Data derived even under optimal conditions in vitro must be extrapolated cautiously to in vivo situations (29). In light of these provocative in vitro findings, our studies were designed to evaluate the maturational changes in PAH extraction in vivo in rabbits, to determine whether penicillin stimulation of PAH extraction could be achieved, and to assess mechanisms which might be responsible for these changes.

\section{MATERIALS AND METHODS}

Studies were performed on groups of 102 New Zealand White rabbit pups on days $10,14,21,28$, and 35 of life. Rabbits were bred in the departmental animal quarters and the young animals were left with their mothers throughout the duration of the injection period. The weights of the pups studied ranged from 135 $\mathrm{g}$ at 10 days to $1150 \mathrm{~g}$ at 35 days of age. Treated and control animals were randomly chosen from each litter without regard to sex or weight. Fifty-four rabbits were injected sc with 30,000 units of procaine penicillin $G$ suspension twice daily during each of four time periods (on days 6-9, 10-13, 17-20, or 24-27 of life). Fifteen rabbits were treated with penicillin on days 6-9 of life. Of these, eight were studied on day $10,24 \mathrm{hr}$ following the last penicillin injection and seven were studied on day 14, 5 days following the final injection. Twenty-one pups were injected with penicillin on days $10-13$ of life; 13 were studied on day 14 and 8 were studied on day 21 of life. Twelve animals were treated with penicillin on days 17-20 and studied on day 21 . Six rabbits were injected with penicillin on days 24-27 and studied on day 28. Forty-eight littermates served as controls, and were similarly injected with isotonic saline. Seven were studied on day 10,13 on day 14,13 on day 21 , and 9 on day 28 of life. Six saline-injected animals were studied at 35 days of age.

The rabbit pups were taken from their mothers and littermates on the morning of study. The body weight of each animal was measured at that time. The rabbits were lightly anesthetized with Inactin, $50-80 \mathrm{mg} / \mathrm{kg}$ body ip. They were placed on a heated operating table, thermostatically controlled, between $38^{\circ}$ and $40^{\circ}$. One jugular vein was exposed and catheterized with PE 50 polyethylene tubing. A volume of isotonic saline equal to $1 \%$ of body weight was administered to replace surgical fluid losses. A prime of $25 \%$ mannitol, $0.25 \mathrm{~g} / \mathrm{kg}$ body wt, was also injected. An infusion followed consisting of PAH, 0.05- $0.2 \mathrm{mg} / \mathrm{min}$ depending on the body weight of the animal; $\left[{ }^{14} \mathrm{C}\right]$ inulin (New England Nuclear), 5 $\mu \mathrm{Ci} / \mathrm{hr}$; and mannitol, $0.25 \mathrm{~g} / \mathrm{kg}$ body weight $/ \mathrm{hr}$ in isotonic saline. The infusion rate was $0.02 \mathrm{ml} / \mathrm{min}$. The quantities of $\mathrm{PAH}_{\text {: }}$ and $\left[{ }^{14} \mathrm{C}\right]$ inulin sustained a plasma PAH level of $3.3-6.5 \mathrm{mg} / 100 \mathrm{ml}$ and a plasma inulin level at least 4 times background. During an equilibration period of at least $40 \mathrm{~min}$, the right ureter was isolated and cannulated. The right and left renal veins were prepared for later puncture. After the equilibration period, two 20-min urine collections were made under mineral oil. Immediately following the second urine collection, the right and left renal veins were punctured with a 25 -gauge beveled needle and $0.2-0.3 \mathrm{ml}$ blood withdrawn. Hemostasis was accomplished. The heart or aorta was then punctured with a 22-gauge needle and a "peripheral" blood 
Table 1. Extraction of $P A H$

\begin{tabular}{|c|c|c|c|c|c|}
\hline & $\begin{array}{c}10 \text { Day } \\
\text { operation, \% }\end{array}$ & $\begin{array}{c}\text { 14-Day } \\
\text { operation, \% }\end{array}$ & $\begin{array}{c}21-\text { Day } \\
\text { operation, \% }\end{array}$ & $\begin{array}{c}28-\text {-Day } \\
\text { operation, \% }\end{array}$ & $\begin{array}{c}\text { 35-Day } \\
\text { operation, \% }\end{array}$ \\
\hline Saline-injected controls & $\begin{array}{c}29.3 \pm 2.4 \\
(n=7)\end{array}$ & $\begin{array}{c}35.9 \pm 3.3 \\
(n=13)\end{array}$ & $\begin{array}{c}59.7 \pm 3.5 \\
(n=13)\end{array}$ & $\begin{array}{c}71.6 \pm 1.9 \\
(n=9)\end{array}$ & $\begin{array}{c}72.7 \pm 2.3 \\
(n=6)\end{array}$ \\
\hline $\mathrm{PCN}^{2}$ injection, 6-9 days & $\begin{array}{c}42.7 \pm 2.4 \\
(n=8)\end{array}$ & $\begin{array}{c}46.7 \pm 3.7 \\
(n=7)\end{array}$ & & & \\
\hline PCN injection, 10-13 days & & $\begin{array}{c}65.0 \pm 3.2 \\
(n=13)\end{array}$ & $\begin{array}{c}57.3 \pm 4.9 \\
(n=8)\end{array}$ & & \\
\hline PCN injection, $17-20$ days & & & $\begin{array}{c}68.7 \pm 2.3 \\
(n=12)\end{array}$ & & \\
\hline PCN injection, 24-27 days & & & & $\begin{array}{c}76.0 \pm 4.1 \\
(n=6)\end{array}$ & \\
\hline
\end{tabular}

${ }^{\prime} \pm$ SE.

${ }^{2}$ Penicillin.

sample obtained. The animals were sacrificed and their kidneys removed, blotted, and weighed on a Mettler balance. Plasma and urine PAH levels were determined by a microadaptation of the method of Bratten and Marshall, as modified by Smith. $\left[{ }^{14} \mathrm{C}\right]$ Inulin in plasma and urine was measured in a liquid scintillation spectrometer (Packard Instrument Co.). Urine volumes were determined by weight on a Mettler balance.

The extraction of PAH $\left(E_{P A H}\right)$ was calculated as [( $A_{P A H}-$ $\left.\left.V_{\text {PAH }}\right) / A_{P A H}\right]$, where $A_{P A H}$ and $V_{\text {PAH }}$ represent $P A H$ concentrations in peripheral vessels and right and left renal veins, respectively. Inulin extractions were determined similarly. Clearances of $\mathrm{PAH}$ and inulin (UV/P), true filtration fraction $\left(E_{I N}\right)$ and renal plasma flow $\left(\mathrm{C}_{\mathrm{PAH}} / \mathrm{E}_{\mathrm{PAH}}\right)$ were calculated. Data are presented as group means $\pm \mathrm{SE}$. Left and right kidney extractions were averaged and $n$ values in all tables represent the number of animals studied. Significance of the differences between the mean values was evaluated by the student's $t$-test. The 0.05 level of probability was used as the criterion of significance.

\section{RESULTS}

The saline-injected control rabbits revealed a stepwise increase in PAH extraction on days 10, 14, 21, and 28 of life (Table 1). $E_{P_{A H}}$ increased from $29.3 \pm 2.4 \%$ SE at 10 days to $35.9 \pm 3.3 \%$ at 14 days, $59.7 \pm 3.5 \%$ at 21 days, and $71.6 \pm 1.9 \%$ at 28 days of life. Significant increments occurred between 14, 21, and 28 days (see Table 2). Pups showed no further increase of extraction of PAH at 35 days of age $(72.7 \pm 2.3 \%)$.

Preinjection of penicillin on days 6-9 significantly increased PAH extraction on day 10 compared to saline-injected controls from $29.3 \pm 2.4 \%$ to $42.7 \pm 2.4 \%$ (see Tables 1 and 2 ). In pups studied on day 14 of life, penicillin treatment either early (on days 6-9) with a 5-day interval before study or directly before study (on days 10-13) significantly enhanced extraction of PAH relative to saline-injected controls studied on day 14 (Tables 1 and 2). $E_{\text {PAH }}$ increased from $35.9 \pm 3.3 \%$ in controls to $46.7 \pm 3.7 \%$ in those treated early and to $65.0 \pm 3.2 \%$ in those treated just before study.

At 21 days of age, a changing pattern emerged. Those animals treated with penicillin on days 17-20 illustrated a significant augmentation of PAH extraction from $59.7 \pm 3.5 \%$ in saline controls to $68.7 \pm 2.3 \%$. In contrast, those animals injected on days $10-13$ and studied on day 21 showed no increase (Tables 1 and 2) in the extraction of PAH. Penicillin injections on days 24-27 did not significantly affect the ability of the 28-day-old animals to extract PAH. E in controls to $76.0 \pm 4.1 \%$ in treated animals.

Mean peripheral plasma PAH levels varied between 3.3 and 6.5 $\mathrm{mg} / 100 \mathrm{ml}$ (Table 3). There was no statistically significant difference in PAH level between any experimental group and its corresponding age-matched control.

Glomerular filtration rate as estimated by inulin clearance $\left(C_{I N}\right)$ increased steadily with age (Table 3 ). GFR increased in controls
Table 2. Statistical analyses of PAH extractions

\begin{tabular}{lc}
\hline \multicolumn{1}{c}{ Groups compared } & $P$ values \\
\hline 10-day control vs. 10-day experimental & $<0.005$ \\
14-day control vs. 14-day experimental (PCN' days 10-13) & $<0.001$ \\
14-day control vs. 14-day experimental (PCN days 6-9) & $<0.05$ \\
14-day experimental (PCN days 10-13) vs. 14-day experi- & $<0.01$ \\
mental (PCN days 6-9) & \\
21-day control vs. 21-day experimental (PCN days 17-20) & $<0.05$ \\
21-day control vs. 21-day experimental (PCN days 10-13) & $\mathrm{NS}$ \\
21-day experimental (PCN days 17-20) vs. 21-day experi- & $<0.05$ \\
mental (PCN days 10-13) & $\mathrm{NS}$ \\
28-day control vs. 28-day experimental (PCN days 24-27) & $\mathrm{NS}$ \\
10-day control vs. 14-day control & $<0.001$ \\
14-day control vs. 21-day control & $<0.005$ \\
21-day control vs. 28-day control & $\mathrm{NS}$ \\
28-day control vs. 35-day control &
\end{tabular}

from $41.2 \pm 9.5 \mu \mathrm{l} / \mathrm{min} \times \mathrm{g}$ kidney at 10 days to $306.6 \pm 21.3$ $\mu \mathrm{l} / \mathrm{min} \times \mathrm{g}$ kidney at 28 days of age. There were no significant differences between the mean inulin clearances of any of the penicillin treated groups and their corresponding controls.

Renal plasma flow as estimated by $\mathrm{C}_{\mathrm{PAH}} / \mathrm{E}_{\mathrm{PAH}}$ increased gradually during the first four weeks of life from $528.8 \pm 120.0 \mu \mathrm{l} / \mathrm{min}$ $\times \mathrm{g}$ kidney at 10 days to $1235.9 \pm 117.1 \mu \mathrm{l} / \mathrm{min} \times \mathrm{g}$ kidney at 28 days. An estimation of the fraction of plasma filtered (true filtration fraction) may be obtained by measuring the extraction of inulin. Mean levels of $E_{I N}$ did not vary significantly with age after 14 days or between penicillin-treated and control groups. Significantly lower values were noted between 10 day and all older animals in both control and penicillin-treated groups $(P<0.005)$. No difference was present between the 10 day experimental and control rabbits.

Body weight, kidney weight, and kidney weight corrected for body weight are tabulated in Table 4 . Mean body weight increased with age in saline injected controls from $180.0 \pm 10.1 \mathrm{~g}$ at 10 days to $560.2 \pm 46.7 \mathrm{~g}$ at 28 days. Kidney weight increased with age from $1.38 \pm 0.05 \mathrm{~g}$ at 10 days to $3.00 \pm 0.17 \mathrm{~g}$ at 28 days. Experimental groups injected either on days 6-9 or on days 10-13 were found to have significantly heavier kidneys on day 14 than the saline-injected controls also studied on day 14 of life $(P<$ 0.001 ). When kidney weights were factored for body weight, the statistically significant difference between the PCN (6-9 days and $10-13$ days) and control groups persisted $(P<0.05)$. No other penicillin-injected group differed in these parameters from its agematched control.

\section{DISCUSSION}

Immaturity of organic anion transport has been noted in human infants $(4,26)$ and in other mammalian neonates, including rabbits $(12,16,17)$. Our data demonstrate, for the first time in vivo, a 
Table 3. Selected renal functions in control and penicillin-treated neonatal rabbits

\begin{tabular}{|c|c|c|c|c|c|c|c|}
\hline Group, age & $\begin{array}{c}\text { No. of } \\
\text { animals }\end{array}$ & Vol, $\mu \mathrm{l} / \mathrm{min}$ & $\begin{array}{c}\mathrm{C}_{\mathrm{IN}}, \\
\mu \mathrm{l} / \mathrm{min} \cdot \mathrm{g} \mathrm{KW} \\
\end{array}$ & $\mathrm{E}_{\mathrm{IN}}, \%$ & $\begin{array}{c}\text { Plasma PAH, } \\
\mathrm{mg} / 100 \mathrm{ml}\end{array}$ & $\begin{array}{c}\mathrm{C}_{\mathrm{PAH}} \mu \mathrm{l} / \mathrm{min} / \cdot \mathrm{g} \\
\mathrm{KW}\end{array}$ & $\begin{array}{c}\mathrm{RPF}\left(\mathrm{C}_{\mathrm{P} \text { 'AH }} / \mathrm{E}_{\mathrm{PAH}}\right), \\
\mu \mathrm{l} / \mathrm{min} \cdot \mathrm{g} \mathrm{KW} \\
\end{array}$ \\
\hline \multirow{2}{*}{ 10-Day control } & 7 & 3.7 & 41.2 & 15.3 & 4.7 & 153.8 & 528.8 \\
\hline & & \pm 0.2 & \pm 9.5 & \pm 1.6 & \pm 0.7 & \pm 30.2 & \pm 120.0 \\
\hline \multirow[t]{2}{*}{ 10-Day exp; PCN days ${ }^{2} 6-9$} & 8 & 4.1 & 52.0 & 16.8 & 5.4 & 197.3 & 498.5 \\
\hline & & \pm 0.3 & \pm 4.2 & \pm 2.1 & \pm 0.9 & \pm 31.8 & \pm 132.4 \\
\hline \multirow{2}{*}{ 14-Day control } & 13 & 5.1 & 94.8 & 26.0 & 5.8 & 282.9 & 647.3 \\
\hline & & \pm 0.3 & \pm 8.2 & \pm 2.3 & \pm 0.5 & \pm 54.2 & \pm 227.9 \\
\hline \multirow{2}{*}{ 14-Day exp; PCN days 10-13 } & 13 & 5.5 & 85.0 & 25.1 & 5.1 & 234.9 & 405.5 \\
\hline & & \pm 0.3 & \pm 6.5 & \pm 2.0 & \pm 0.4 & \pm 25.2 & \pm 75.3 \\
\hline \multirow[t]{3}{*}{ 14-Day exp; PCN days 6-9 } & 7 & 4.2 & 83.4 & 27.6 & 4.7 & 188.9 & 444.5 \\
\hline & & \pm 0.4 & \pm 10.8 & \pm 2.1 & \pm 0.8 & \pm 34.2 & \pm 140.5 \\
\hline & & 8.4 & 166.5 & 28.7 & 5.1 & 414.1 & 706.3 \\
\hline 21-Day control & 13 & \pm 0.4 & \pm 18.6 & \pm 1.9 & \pm 0.5 & \pm 64.3 & \pm 180.6 \\
\hline \multirow{2}{*}{$\begin{array}{l}\text { 21-Day exp; PCN days } \\
17-20^{2}\end{array}$} & & 6.6 & 108.8 & 28.1 & 6.5 & 331.7 & 507.1 \\
\hline & 12 & \pm 0.6 & \pm 17.5 & \pm 2.1 & \pm 0.4 & \pm 50.2 & \pm 112.6 \\
\hline \multirow{3}{*}{$\begin{array}{l}\text { 21-Day exp; PCN Days } \\
\text { 10-13 }\end{array}$} & & 6.8 & 105.3 & 26.1 & 6.5 & 376.3 & 670.8 \\
\hline & 8 & \pm 0.5 & \pm 15.2 & \pm 2.6 & \pm 0.7 & \pm 64.5 & \pm 184.6 \\
\hline & & 12.3 & 306.6 & 22.7 & 3.3 & 959.6 & 1235.9 \\
\hline \multirow{3}{*}{$\begin{array}{l}\text { 28-Day control } \\
28 \text { Day exp PCN days } \\
24-27\end{array}$} & 9 & \pm 0.5 & \pm 21.3 & \pm 5.1 & \pm 0.7 & \pm 88.9 & \pm 117.1 \\
\hline & & 13.4 & 267.4 & 26.1 & 5.6 & 728.6 & 908.4 \\
\hline & 6 & \pm 0.6 & \pm 34.0 & \pm 5.1 & \pm 0.6 & \pm 91.8 & \pm 168.5 \\
\hline
\end{tabular}

' Data presented as mean \pm 1 SE. $C_{\mathrm{IN}}$ : clearance of inulin; $\mathrm{C}_{\mathrm{PAH}}$ : clearance of $\mathrm{PAH} ; \mathrm{C}_{\mathrm{PAH}} / \mathrm{E}_{\mathrm{PAH}}$ : renal plasma flow; $\mathrm{E}_{\mathrm{IN}}$ : extraction of inulin; $\mathrm{KW}$ : kidney weight.

${ }^{2}$ PCN days: penicillin injected twice daily on each of the days indicated.

Table 4. Body weight, kidney weight

\begin{tabular}{lccccc}
\hline & & & Body & Kidney & Kidney wt, \\
\cline { 4 - 6 } & & $n^{1}$ & wt, g & wt, g & lo0 g body wt \\
\hline 10-Day control & & 7 & 180.0 & 1.38 & 0.76 \\
& & & \pm 10.1 & \pm 0.05 & \pm 0.02 \\
10-Day (PCN & $6-9$ & 8 & 184.4 & 1.47 & 0.80 \\
days) & & & \pm 11.7 & \pm 0.06 & \pm 0.03 \\
14-Day Control & & 13 & 224.2 & 1.47 & 0.67 \\
& & & \pm 10.4 & \pm 0.04 & \pm 0.02 \\
14-Day (PCN & $10-13$ & 13 & 248.4 & $1.77^{2}$ & $0.72^{2}$ \\
days) & & & \pm 12.6 & \pm 0.04 & \pm 0.02 \\
14-Day (PCN & $6-9$ & 7 & 231.9 & $1.78^{2}$ & $0.78^{2}$ \\
days) & & & \pm 12.1 & \pm 0.04 & \pm 0.04 \\
21-Day control & & 13 & 329.0 & 1.93 & 0.63 \\
& & & \pm 25.8 & \pm 0.08 & \pm 0.02 \\
21-Day (PCN & $17-20$ & \multirow{2}{*}{12} & 299.0 & 1.95 & 0.67 \\
days) & & & \pm 20.5 & \pm 0.07 & \pm 0.03 \\
21-Day (PCN & $10-13$ & 8 & 325.3 & 2.15 & 0.67 \\
days) & & & \pm 21.8 & \pm 0.08 & \pm 0.03 \\
28-Day control & & 9 & 560.2 & 3.00 & 0.54 \\
& & & \pm 46.7 & \pm 0.17 & \pm 0.02 \\
28-Day (PCN 24-27 & 6 & 417.0 & 2.52 & 0.59 \\
days) & & & \pm 14.0 & \pm 0.11 & \pm 0.04 \\
\hline
\end{tabular}

${ }^{1}$ Number of animals.

${ }^{2}$ Significantly different than control.

progressive increase in the ability of the rabbit kidney to extract PAH throughout the neonatal period.

Saline-injected control animals had increasing inulin and $\mathrm{PAH}$ clearance even when corrected for kidney weight with increasing age from 10-28 days of life. PAH extraction increased significantly in control rabbit pups between 2 and 4 weeks of life. Its ascent slowed markedly during the fifth week, as the pups attained adult extraction capability.

An attempt was made to stimulate increased extraction of the kidney of this organic anion during the neonatal period. There is evidence that a single concentrating step exists facilitating $\mathrm{PAH}$ transport from peritubular capillary, through tubular cells and into the tubular lumen $(5,7)$. Several compounds with structural similarities are thought to share this pathway of secretion. One of these, penicillin, was chosen as a "pretreatment" in an effort to identify and to stimulate the mechanism(s) responsible for the secretion of PAH.

Hirsch and Hook and others $(8-10,13,20)$ have demonstrated in vitro that the administration of exogenous anionic substances enhance the ability of renal cortical slices to transport PAH. Our data in vivo show that penicillin injection prior to functional study enhances the extraction of PAH compared to controls preinjected with an equal volume of saline. This stimulation was found in groups of rabbit pups from 10-21 days of age studied $24 \mathrm{hr}$ after the last in a 4-day series of penicillin injections. The induced increment in PAH extraction was most pronounced on the 14th day of life after penicillin treatment on days 10-13. This experimental group attained levels of $\mathrm{E}_{\mathrm{PAH}}$ approximating those seen at 21-28 days in the control animals. An increase in PAH extraction compared to controls was not observed in those animals that were administered their last dose of penicillin on day 27 and studied on day 28 of life. Adult levels of $\mathrm{E}_{\mathrm{PAH}}$ (those observed in 28- and 35day controls) were not exceeded by any of the penicillin-stimulated groups. Rabbits preinjected with penicillin on days 6-9 but with their study delayed 5 days showed a blunted response. This group demonstrated a significant increment in $\mathrm{E}_{\mathrm{PAH}}$ compared to controls, although it was of a smaller magnitude than those studied immediately after their penicillin treatment (Table 2). The 21-day group, studied 7 days after the last injection of penicillin, did not show augmentation of $E_{\mathrm{PAH}}$. These findings suggest that until the mechanism responsible for extraction of PAH reaches mature levels, preinjection with penicillin results in enhancement of $\mathrm{PAH}$ removal. Data obtained from animals studied 5-7 days after penicillin pretreatment indicate that the effect of anion administration on PAH extraction is transient.

The increased removal of PAH by the kidney could be related to growth (i.e., an increase in the number and/or size of proximal tubular transport sites associated with increased kidney weight), a shift in the distribution of renal blood flow to structurally and functionally more mature areas of the renal cortex, or the maturation or stimulation of a specific or nonspecific transport mechanism located within already existing tubular structures.

Enhanced extraction of PAH might be the result of enhanced growth. Microdissection studies have shown that proximal tubular length increases slowly during the early neonatal period, followed by an acceleration of linear growth. This increase in functional 
area with an accompanying increment in transport sites and enzymatic activity (22) could be responsible for the changing transport capability in normal development and in substrate stimulated animals. Kidney weight was increased in those rabbits demonstrating the greatest enhancement of PAH extraction (14day penicillin stimulated rabbits). Wet kidney weight was significantly greater in both penicillin treated groups studied on day 14 of life.

This weight increase was not related to body weight in those injected on days 6-9 or 10-13 as the statistical differences persisted when kidney weight was factored for body weight. It is possible that penicillin may stimulate protein synthesis and growth in the kidney at least at 2 weeks of age.

Structurally, the kidneys of newborn rabbits have a persistent nephrogenic zone in the outer cortex. The immature kidney perfuses the juxtamedullary nephrons with a relatively large fraction of total renal blood flow, thus bypassing secretory sites of PAH $(18,22)$. An alteration in the distribution of renal blood flow to a more peripheral pattern could account for the observed increase in PAH extraction. Direct measurements of renal blood flow distribution are needed to clarify this possibility.

The presence of increased substrate may enhance the transfer of PAH from capillary to lumen in existing functional units of the proximal tubule. Increased concentration of substrate results in greater reaction velocity in many enzymatically mediated interactions (27). Penicillin acting as a substrate in this instance may augment the formation of enzyme or carrier for transport of penicillin and/or PAH.

Recently, investigations into renal organic anion binding proteins (ligandin), have been reported (14). It has been suggested that this substance, identical to the $y$ protein isolated from liver, may function in the proximal tubular cell as a component of the renal organic anion transport system. Penicillin may influence the role of such a transport protein. This study provides no evidence for or against the induction of ligandin synthesis by penicillin.

In summary, our data demonstrate that in vivo extraction of PAH reaches mature levels in the rabbit by 28 days of life. Penicillin injection during maturation results in enhancement of PAH extraction. The magnitude of this stimulation decreases as maturation is neared and the enhancement appears to be transitory. Increased kidney weight is seen in those animals demonstrating the greatest increment of $\mathrm{E}_{\mathrm{PAH}}$ after penicillin treatment. It appears most likely that the stimulation of the mechanism(s) responsible for PAH removal by the kidney is related to substrate availability and its effects on metabolic, enzyme-related processes occurring at existing tubular transport sites. A concomitant increase in the size and number of the kidney's functional elements may be contributory at 2 weeks of age.

\section{REFERENCES AND NOTES}

1. Beyer, K. H., Peters, L., Woodward, R., and Verwey, W. F.: The enhancement of the physiological economy of penicillin in dogs by the simultaneous administration of PAH. J. Pharmacol. Exp. Ther., 82: 310 (1944).

2. Calcagno, P. L., and Rubin, M. I.: Renal extraction of para-aminohippurate in infants and children. J. Clin. Invest., 42: 1632 (1963).

3. Cross, R. J., and Taggart, J. V.: Renal tubular transport: accumulation of p- aminohippurate by rabbit kidney slices. Amer. J. Physiol., 161: 181 (1950).

4. Edelmann, C. M., Jr.: Maturation of the neonatal kidney. Proceedings of the Third International Congress on Nephrology, Washington. D.C.. Vol. 3. pp. $1-12$ (1966).

5. Foulkes, E. C.: Kinetics of p-aminohippurate secretion in the rabbit. Amer. J. Physiol., 205: 1019 (1963).

6. Foulkes. E. C.. and Miller. B. F.: Steps in p-aminohippurate transport by kidney slices. Amer. J. Physiol., 196: 86 (1959).

7. Foulkes, E. C.. and Miller, B. F.: Transport of p-aminohippurate from cell to lumen in kidney tubule. Amer. J. Physiol., 196: 83 (1959).

8. Hirsch, G. H., and Hook, J. B.: Maturation of renal organic acid transport Substrate stimulation by penicillin. Science, 165: 909 (1969).

9. Hirsch. G. H., and Hook. J. B.: Maturation of renal organic acid transport: substrate stimulation by penicillin and $p$-aminohippurate. J. Pharmacol. Exp. Ther., 17l: 103 (1970).

10. Hirsch, G., and Hook, J. B.: Stimulation of renal organic acid transport and protein synthesis by penicillin. J. Pharmacol. Exp. Ther.. 174: 152 (1970).

11. Hirsch, G., and Pakuts. A.: Development of $p$-aminohippurate transport and oxygen consumption in rabbit kidneys. Biochem. Pharmacol.. 23: 2323 (1974).

12. Horster, M., and Lewy. J. E.: Filtration fraction and extraction of PAH during neonatal period in the rat. Amer. J. Physiol., 219: 1061 (1970).

13. Kim. J. K., Hirsch. G. H.. and Hook. J. B.: In vitro analysis of organic ion transport in renal cortex of the newborn rat. Pediat. Res.. 6: 600 (1972).

14. Kirsch, R.. Fleischner. G.. Kamisaka. K.. and Arias. I. M.: Structural and functional studies of ligandin. J. Clin. Invest., 55: 1009 (1975).

15. Kleinman. L. I., and Lubbe. R. J.: Factors affecting the maturation of renal PAH extraction in the newborn dog. Amer. J. Physiol.. 223: 411 (1972).

16. Lubbe. R. J., and Kleinman. L. I.: Factors affecting glomerular filtration rate and renal plasma flow in puppies. J. Pediat., 76: 961 (1970).

17. Moore, E. S., Satrosook, S. S., Fine, B. P., Katz. M. C., and Edelmann, C. M., Jr.: Renal extraction in puppies. Third Annual Meeting of the American Society of Nephrology. p. 49 (1969).

18. Moore, E. S., Satrosook, S. S.. Fine, B. P., Katz. M. C.. and Edelmann. C. M. Jr.: Renal PAH extraction in puppies. 39th Annual Meeting of the Society of Pediatric Research, Atlantic City. NJ. Vol. 2. p. 3 (1969).

19. Orten, J. M.. and Neuhaus, O. W.: Human Biochemistry. Ed. 9. p. 140 (The C.V. Mosby Co.. St. Louis, 1975).

20. Pegg. D. G., and Hook. J. B.: Pharmacodynamic analysis of substrate stimulation of $p$-aminohippurate transport by newborn rabbit kidney. J. Pharmacol. Exp. Ther., 195: 16 (1975).

21. Rennick, B.. Hamilton, B., and Evans, R.: Development of renal tubular transpon of TEA and PAH in the puppy and piglet. Amer. J. Physiol.. 201: 743 (1961).

22. Spitzer, A., and Brandis. M.: Functional and morphologic maturation of the superficial nephrons. J. Clin. Invest.. 53: 279 (1974).

23. Tune. B. M., Burg, M. B., and Patlack, C.: Characteristics of $p$-aminohippurate transport in proximal renal tubules. Amer. J. Physiol.. 217: 1057 (1969).

24. Wachstein, M., and Bradshaw, M.: Histochemical localization of enzyme activity in the kidneys of three mammalian species during the postnatal development. J. Histochem. Cytochem., 13: 44 (1965).

25. Wedeen, R. P., and Weiner. B.: The distribution of $p$-aminohippuric acid in rat kidney slices. Kidney Intern., 3: 205 (1973).

26. West, J. R., Smith, H. W., and Chasis. H.: Glomerular filtration rate, renal blood flow and maximal tubular excretory capacity in infancy. J. Pediat.. 32: 10 (1948).

27. White. A., Handler. P.. and Smith. E. L.: Principles of Biochemistry. Ed. S. p. 243 (McGraw Hill, New York, 1973).

28. Williamson. R. C.. and Hiatt, E. P.: Development of renal function in fetal and neonatal rabbits using phenosulfonphthalein. Proc. Soc. Exp. Biol. Med.. 66: 554 (1947).

29. Youdim, M. B. H., and Woods, H. F.: The influence of tissue environment on the rates of metabolic process and the properties of enzymes. Biochem. Pharmacol., p. 317 (1975).

30. The authors thank Ms. Deborah Grosser and Ms. Bama Rucker for their technical assistance.

31. This research was supported in part by NIH Training Grant HD-00383 and New York State Health Research Council Grant 132.

32. Requests for reprints should be addressed to: Dr. John E. Lewy. Department of Pediatrics, Tulane University School of Medicine. New Orleans, LA (USA). 33. Received for publication April 12, 1977.

34. Accepted for publication October 18, 1977 